\title{
Penerapan Perhitungan Biaya Relevan dalam Pengambilan Keputusan Pesanan Khusus Rita Martini ${ }^{1)}$, M. Thoyib $^{2)}$, Yulita ${ }^{3)}$ \\ 1), 2) 3) Jurusan Akuntansi/Politeknik Negeri Sriwijaya \\ Jalan Srijaya Negara, Bukit Besar, Palembang, Kode Pos 30139

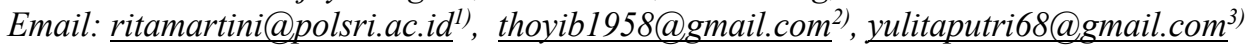

\begin{abstract}
Companies in making decisions must consider information about costs incurred. One of the important information needed by companies in making decisions for production activities is information about relevant costs. The information needed about relevant costs is to find out the calculation of relevant costs in determining the decision to accept or reject specific requests from buyers. The results show that company management needs to take into account the relevant costs in making decisions to accept or reject special orders. Furniture companies must classify relevant costs first before making a decision to accept orders to minimize losses, and can be used as a strategy to increase profits.
\end{abstract}

Keywords: decision making, cost accounting

\section{ABSTRAK}

Perusahaan dalam mengambil keputusan harus mempertimbangkan informasi tentang biaya yang dikeluarkan. Salah satu informasi penting yang dibutuhkan perusahaan dalam pengambilan keputusan untuk kegiatan produksi adalah informasi tentang biaya relevan. Informasi yang dibutuhkan tentang biaya relevan adalah untuk mengetahui perhitungan biaya relevan dalam menentukan keputusan untuk menerima atau menolak permintaan spesifik dari pembeli. Hasil penelitian menunjukkan manajemen perusahaan perlu memperhitungkan biaya relevan dalam membuat keputusan untuk menerima atau menolak pesanan khusus. Perusahaan furniture harus mengklasifikasikan biaya relevan terlebih dahulu sebelum membuat keputusan menerima pesanan untuk meminimalkan kerugian, dan dapat digunakan sebagai strategi untuk meningkatkan keuntungan.

Kata Kunci: pengambilan keputusan, akuntansi biaya

\section{Pendahuluan}

Manajemen dalam menjalankan kegiatan usahanya sering dihadapkan pada beberapa alternatif. Berdasarkan berbagai alternatif tersebut, manajemen harus memilih satu dari alternatif tersebut. Selain itu manajemen harus mengambil keputusan yang paling tepat dengan menjalankan fungsi-fungsi manajemennya sebaik mungkin agar mempunyai kemampuan bersaing di pasar (Martini, Thoyib, Periansya, 2018). Berhasil atau tidaknya dalam mencapai tujuan perusahaan ditandai dengan kemampuan manajemen dalam melihat kemungkinan dan kesempatan di masa yang akan datang baik jangka pendek maupun jangka panjang (Martini, Zulkifli, Sukmini, \& Armaini, 2018).

Salah satu masalah yang seringkali dihadapi manajemen adalah mengenai pengambilan keputusan dalam menerima atau menolak pesanan khusus. Manajemen harus menganalisis biaya-biaya yang terkait dengan pesanan produk (Z., Martini, \& Agustin, 2019). Lalu perusahaan dapat menentukan alternatif keputusan yang akan diambil dalam menerima atau menolak pesanan khusus tersebut. Analisis yang digunakan dalam hal ini adalah apakah pesanan khusus tersebut memberikan tambahan laba bagi perusahaan, walau harga jual dari pesanan khusus tersebut lebih rendah dari harga jual produk normalnya (Rohana \& Sunrowyati, 2016).

Informasi mengenai biaya (Lanen, Anderson, \& Maher, 2017).perlu diperhatikan oleh setiap perusahaan karena digunakan dalam menetapkan harga, efisiensi penggunaan sumber daya, dan bahkan evaluasi tentang lini produk yang paling menguntungkan. Jumlah biaya dibutuhkan (Z., Martini, \& Agustin, 2019) untuk memantau dukungan berbagai fungsi dalam bisnis termasuk keputusan yang menyangkut berbagai pilihan alternatif. Salah satu informasi penting untuk perencanaan dan pengambilan keputusan adalah mengenai informasi analisis biaya relevan (Wibowo \& Purwanugraha, 2012).

Biaya relevan (Lanen, Anderson, \& Maher, 2017) adalah biaya masa yang akan datang yang berbeda besarnya pada berbagai alternatif. Seluruh keputusan yang diambil oleh manajemen perusahaan pastilah berhubungan dengan masa yang akan datang. Oleh karena itu, hanya biaya mendatang saja yang relevan bagi sebuah keputusan menerima atau menolak pesanan khusus. Biaya relevan yang ditimbulkan perusahaan akan dianalisis 
tertentu sangat besar tetapi tidak memberikan hasil yang optimal maka departemen yang bersangkutan akan ditutup, sebaliknya jika departemen lain memerlukan biaya yang relatif kecil namun memberikan hasil yang optimal sesuai target perusahaan maka keberadaan departemen tersebut akan diteruskan. Diharapkan dengan cara ini dapat menghasilkan kinerja yang lebih baik sesuai dengan tujuan perusahaan dan dapat membantu perusahaan dalam mempertahankan bisnisnya dalam menghadapi persaingan bisnis yang semakin ketat (Martini, Thoyib, Periansya, 2018). Biaya relevan (Tumilantouw, Morasa, \& Kalangi, 2014), meliputi biaya bahan baku, biaya tenaga kerja langsung, dan biaya overhead pabrik.

Menteri Perindustrian Airlangga Hartarto mengungkapkan pemerintah telah memfokuskan untuk mengembangkan industri manufaktur yang menitikberatkan pada sektor pengolahan sumber daya alam, berorientasi ekspor, dan padat karya. Hal tersebut bertujuan untuk mengoptimalkan industri perkebunan yang ada sehingga hasil perkebunan bisa dimanfaatkan dengan sebaik mungkin (Pers, 2019). Industri manufaktur dianggap mampu memberikan berbagai keuntungan diantaranya meningkatkan penghasilan negara melalui devisa dari kegiatan ekspor yang dilakukan, membuka lapangan pekerjaan bagi masyarakat di sekitar perusahaan manufaktur, dan mengoptimalkan penggunaaan sumber daya alam yang ada di Indonesia (Istimewa, 2017).

Dalem Agung Furniture, merupakan industri manufaktur yang bergerak pada bidang pembuatan furniture yang berbahan dasar kayu jati dan kayu HPL. Usaha seperti ini tentu memberikan dampak yang baik karena dapat memberikan lapangan pekerjaan bagi masyarakat di sekitar perusahaan. Usaha ini juga dapat menjadi ladang bagi petani jati untuk mendistribusikan hasil perkebunannya. Selain menjual produk hasil produksi rutinnya seperti lemari pakaian, satu set meja makan, tempat tidur, dan meja belajar. Dalem Agung Furniture juga kadang mendapatkan pesanan khusus yang harus sesuai dengan keinginan pelanggan, Kursi Tamu Monalisa pada tahun 2017, Kursi Tamu Gloria dan Kursi Tamu Ganesha pada tahun 2018, dan pada tahun 2019 menerima pesanan khusus Meja Ketapang yang berbeda ukuran dari produksi biasanya. Perusahaan mengalami kesulitan untuk mengambil keputusan saat memperoleh pesanan khusus tersebut karena bahan baku yang digunakan untuk memproduksi pesanan khusus tersebut belum pernah diperhitungkan sehingga tidak ada catatan atas biaya bahan baku yang harus dikeluarkan. Agar keputusan yang diambil tepat, sebaiknya manajemen bisa melakukan analisis pada alternatif keputusan dengan menggunakan biaya relevan untuk menentukan apakah pesanan dapat diterima atau ditolak.

\section{Pembahasan}

Pengklasifikasian biaya pada Dalem Agung Furniture dibedakan berdasarkan elemen biaya produksi, yaitu:

1. Biaya bahan baku adalah nilai bahan baku yang digunakan dalam proses produksi untuk diubah menjadi produk jadi.

2. Biaya tenaga kerja langsung adalah besarnya nilai gaji dan upah tenaga kerja yang terlibat langsung untuk mengerjakan produk.

3. Biaya overhead pabrik adalah semua biaya produksi selain biaya bahan baku dan biaya tenaga kerja langsung.

2.1 Analisis Pemisahan Biaya Relevan dan Biaya Tidak Relevan

Analisis menggunakan biaya relevan akan menghilangkan beberapa akun-akun biaya seperti biaya overhead pabrik dan biaya non produksi yang telah ditetapkan untuk satu periode (Tumilantouw, Morasa, \& Kalangi, 2014). Gambaran klasifikasi biaya relevan dan biaya tidak relevan suatu produk pesanan khusus disajikan pada Tabel 1 sampai dengan Tabel 4.

Tabel 1. Biaya Relevan dan Biaya Tidak Relevan untuk Pesanan Khusus 1 Unit Kursi Tamu Monalisa

\begin{tabular}{lrrr}
\hline \multicolumn{1}{c}{ Keterangan } & Total Biaya (Rp) & Biaya Relevan (Rp) & Biaya Tidak Relevan (Rp) \\
\hline Biaya Bahan Baku Langsung: & & & - \\
Papan Jati & 4.275 .000 & 4.275 .000 & - \\
Kaca & 75.000 & 75.000 & - \\
Kayu Balok & 1.000 .000 & 1.000 .000 & - \\
Busa Grade B & 208.000 & 208.000 & - \\
Biaya Tenaga Kerja Langsung: & & & - \\
Bagian Pembuat Pola & 120.000 & 120.000 & - \\
Bagian Perakitan & 180.000 & 180.000 & - \\
Bagian Jok/Sofa/Busa & 180.000 & 180.000 & - \\
Bagian Finishing & 150.000 & 150.000 & $142.222,22$ \\
Biaya Overhead Pabrik: & & & - \\
Biaya Bahan Baku Tidak Langsung & 1.341 .000 & 1.341 .000 & $115.575,62$ \\
Biaya Tenaga Kerja Tidak Langsung & $142.222,22$ & - & \\
Biaya Listrik & 1.733 & 1.733 & $53.333,33$ \\
Biaya Penyusutan Aset Tetap & $115.575,62$ & - & \\
Biaya Lain-Lain & $53.333,33$ & - & \\
\hline \multicolumn{1}{r}{ Total } & $7.841 .864,17$ & & \\
\hline
\end{tabular}


Sumber: Data yang diolah (2020)

Tabel 2. Biaya Relevan dan Biaya Tidak Relevan untuk Pesanan Khusus 1 Unit Kursi Tamu Gloria

\begin{tabular}{|c|c|c|c|}
\hline Keterangan & Total Biaya (Rp) & Biaya Relevan (Rp) & Biaya Tidak Relevan (Rp) \\
\hline \multicolumn{4}{|l|}{ Biaya Bahan Baku Langsung: } \\
\hline Papan Jati & 2.350 .000 & 2.350 .000 & - \\
\hline Kaca & 78.000 & 78.000 & - \\
\hline Kayu Balok & 1.000 .000 & 1.000 .000 & - \\
\hline Busa Grade A & 600.000 & 600.000 & - \\
\hline \multicolumn{4}{|l|}{ Biaya Tenaga Kerja Langsung: } \\
\hline Bagian Pembuat Pola & 130.000 & 130.000 & - \\
\hline Bagian Perakitan & 195.000 & 195.000 & - \\
\hline Bagian Jok/Sofa/Busa & 200.000 & 200.000 & - \\
\hline Bagian Finishing & 130.000 & 130.000 & - \\
\hline \multicolumn{4}{|l|}{ Biaya Overhead Pabrik: } \\
\hline Biaya Bahan Baku Tidak Langsung & 1.294 .000 & 1.294 .000 & - \\
\hline Biaya Tenaga Kerja Tidak Langsung & $155.555,56$ & - & $155.555,56$ \\
\hline Biaya Listrik & 1.321 & 1.321 & - \\
\hline Biaya Penyusutan Aset Tetap & $115.575,62$ & - & $115.575,62$ \\
\hline Biaya Lain-Lain & $54.444,44$ & - & $54.444,44$ \\
\hline Total & $6.303 .896,62$ & 5.978 .321 & $325.575,62$ \\
\hline
\end{tabular}

Sumber: Data yang diolah (2019)

Tabel 3. Biaya Relevan dan Biaya Tidak Relevan untuk Pesanan Khusus 1 Unit Kursi Tamu Ganesha

\begin{tabular}{|c|c|c|c|}
\hline Keterangan & Total Biaya (Rp) & Biaya Relevan (Rp) & Biaya Tidak Relevan (Rp) \\
\hline \multicolumn{4}{|l|}{ Biaya Bahan Baku Langsung: } \\
\hline Papan Jati & 4.935 .000 & 4.935 .000 & - \\
\hline Kaca & 78.000 & 78.000 & - \\
\hline Kayu Balok & 1.000 .000 & 1.000 .000 & - \\
\hline Busa Grade A & 750.000 & 750.000 & - \\
\hline \multicolumn{4}{|l|}{ Biaya Tenaga Kerja Langsung: } \\
\hline Bagian Pembuat Pola & 130.000 & 130.000 & - \\
\hline Bagian Perakitan & 195.000 & 195.000 & - \\
\hline Bagian Jok/Sofa/Busa & 200.000 & 200.000 & - \\
\hline Bagian Finishing & 130.000 & 130.000 & - \\
\hline \multicolumn{4}{|l|}{ Biaya Overhead Pabrik: } \\
\hline Biaya Bahan Baku Tidak Langsung & 1.751 .000 & 1.751 .000 & - \\
\hline Biaya Tenaga Kerja Tidak Langsung & $155.555,56$ & - & $155.555,56$ \\
\hline Biaya Listrik & 1.321 & 1.321 & - \\
\hline Biaya Penyusutan Aset Tetap & $115.575,62$ & - & $115.575,61$ \\
\hline Biaya Lain-Lain & $54.444,44$ & - & $54.444,44$ \\
\hline Total & $9.495 .896,62$ & 9.170 .321 & $325.575,62$ \\
\hline
\end{tabular}

Sumber: Data yang diolah (2020)

Tabel 4. Biaya Relevan dan Biaya Tidak Relevan untuk Pesanan Khusus 1 Unit Meja Ketapang

\begin{tabular}{lrrr}
\hline \multicolumn{1}{c}{ Keterangan } & Total Biaya (Rp) & Biaya Relevan (Rp) & Biaya Tidak Relevan (Rp) \\
\hline Biaya Bahan Baku Langsung: & & & - \\
Papan Jati & 1.000 .000 & 1.000 .000 & - \\
Kaca & 80.000 & 80.000 & - \\
Biaya Tenaga Kerja Langsung: & & & - \\
Bagian Pembuat Pola & 150.000 & 150.000 & - \\
Bagian Perakitan & 225.000 & 225.000 & - \\
Bagian Jok/Sofa/Busa & 240.000 & 240.000 & 150.000 \\
Bagian Finishing & 150.000 & & \\
\hline
\end{tabular}




\begin{tabular}{|c|c|c|c|}
\hline Keterangan & Total Biaya (Rp) & Biaya Relevan (Rp) & Biaya Tidak Relevan (Rp) \\
\hline Biaya Overhead Pabrik: & & & \\
\hline Biaya Bahan Baku Tidak Langsung & 467.500 & 467.500 & - \\
\hline Biaya Tenaga Kerja Tidak Langsung & $182.222,22$ & - & $182.222,22$ \\
\hline Biaya Listrik & 869 & 869 & $x^{2}+3$ \\
\hline Biaya Penyusutan Aset Tetap & $115.575,62$ & - & $115.575,62$ \\
\hline Biaya Lain-Lain & $57.777,77$ & - & $57.777,77$ \\
\hline Total & $2.668 .944,61$ & $\mathrm{Rp} 2.313 .369$ & $355.575,61$ \\
\hline
\end{tabular}

Sumber: Data yang diolah (2020)

Biaya relevan untuk pesanan khusus 1 unit Kursi Tamu Monalisa sebesar Rp 7.530.733 dan biaya tidak relevan sebesar Rp 311.131,17; biaya relevan untuk pesanan khusus 1 unit Kursi Tamu Gloria adalah Rp 5.978.321 dan biaya tidak relevan sebesar Rp 325.575,62; biaya relevan untuk pesanan khusus Kursi Tamu Ganesha adalah Rp 9.170.321 dan biaya tidak relevan sebesar Rp 325.575,62; dan biaya relevan untuk pesanan khusus Meja Ketapang sebesar Rp 2.313.369 dan biaya tidak relevan sebesar Rp 355.575,61.

Biaya tenaga kerja tidak langsung, beban penyusutan aset tetap, dan biaya lain-lain termasuk ke dalam biaya tidak relevan, karena biaya-biaya tersebut merupakan biaya tetap yang akan selalu ada dan tidak akan terpengaruh oleh jumlah produksi. Artinya, biaya perbulan yang harus dikeluarkan perusahaan untuk biaya tenaga kerja tidak langsung, beban penyusutan aset tetap, dan biaya lain-lain akan tetap sama walaupun jumlah unit produksi yang dihasilkan setiap bulannya berbeda.

2.2 Analisis Perhitungan Biaya Relevan dalam Pengambilan Keputusan Pesanan Khusus

Biaya relevan (Lanen, Anderson, \& Maher, 2017:103) adalah biaya masa mendatang dalam berbagai alternatif untuk mengambil keputusan manajemen. Biaya dapat dikatakan relevan untuk keputusan tertentu (Salman \& Farid, 2016:179) apabila biaya tersebut berbeda atau berubah jika tindakan alternatif diambil. Aplikasi biaya relevan dalam pengambilan keputusan (Siregar, Suripto, Hapsoro, Lo, \& Biyanto, 2017) adalah: 1) keputusan membuat atau membeli, 2) keputusan mempertahankan atau menghentikan, 3) keputusan pesanan khusus, dan 4) keputusan menjual atau memproses lebih lanjut.

Tiga alasan pembuatan keputusan memerlukan biaya relevan dalam mengambil keputusan (Siregar, Suripto, Hapsoro, Lo, \& Biyanto, 2017) adalah:

1. Tidak semua biaya merupakan biaya relevan. Informasi biaya yang tidak relevan dapat diabaikan dalam pembuatan keputusan tertentu karena yang diperlukan adalah biaya yang relevan saja.

2. Produksi merupakan informasi yang mahal. Apabila akuntan manajemen hanya menyediakan biaya relevan saja, maka ia dapat mengurangi aktivitas pengumpulan dan pengolahan informasi. Selain itu, akuntan manajemen juga dapat menghemat waktu, perlengkapan, dan sumber daya lain dalam memasok informasi.

3. Kemampuan kognitif yang terbatas. Terlalu banyak informasi dapat menyebabkan pembuat keputusan menjadi kurang rasional. Hal tersebut disebabkan oleh sulitnya pembuat keputusan dalam mengorganisasikan dan menggunakan informasi yang berlebihan.

Penerapan biaya relevan (Rohana \& Sunrowiyati, 2016) akan mempermudah perusahaan untuk mengambil keputusan dalam kaitannya pesanan khusus tersebut akan diterima atau ditolak. Gambaran analisis perhitungan biaya relevan dalam mengambilan keputusan menerima atau menolak pesanan khusus atas suatu produk dipaparkan pada Tabel 5 sampai dengan Tabel 8.

Tabel 5. Biaya Relevan pada Pesanan Khusus 1 Unit Kursi Tamu Monalisa

\begin{tabular}{lrrr}
\hline \multicolumn{1}{c}{ Keterangan } & Menerima (Rp) & Menolak (Rp) & Manfaat Jika Menerima (Rp) \\
\hline Pendapatan & 8.000 .000 & 0 & 8.000 .000 \\
Bahan Baku Langsung & & & $(4.275 .000)$ \\
Papan Jati & $(4.275 .000)$ & 0 & $(75.000)$ \\
Kaca & $(75.000)$ & 0 & $(1.000 .000)$ \\
Kayu Balok & $(1.000 .000)$ & 0 & $(208.000)$ \\
Busa Grade B & $(208.000)$ & 0 & $(120.000)$ \\
Tenaga Kerja Langsung & & & $(180.000)$ \\
Bagian Pembuat Pola & $(120.000)$ & 0 & $(180.000)$ \\
Bagian Perakitan & $(180.000)$ & 0 & 0 \\
Bagian Jok/Sofa/Busa & $(180.000)$ & & \\
\end{tabular}




\begin{tabular}{|c|c|c|c|}
\hline Keterangan & Menerima (Rp) & Menolak (Rp) & Manfaat Jika Menerima (Rp) \\
\hline Bagian Finishing & $(150.000)$ & 0 & $(150.000)$ \\
\hline \multicolumn{4}{|l|}{ Biaya Overhead Pabrik } \\
\hline Biaya Bahan Baku Tidak Langsung & $(1.341 .000)$ & 0 & $(1.341 .000)$ \\
\hline Biaya Listrik & $(1.733)$ & 0 & $(1.733)$ \\
\hline Total & 469.267 & 0 & 469.267 \\
\hline
\end{tabular}

Sumber: Data yang diolah (2020)

Tabel 6. Biaya Relevan pada Pesanan Khusus 1 Unit Kursi Tamu Gloria

\begin{tabular}{lrrr}
\hline \multicolumn{1}{c}{ Keterangan } & Menerima (Rp) & Menolak (Rp) & Manfaat Jika Menerima (Rp) \\
\hline Pendapatan & 6.900 .000 & 0 & 6.900 .000 \\
Bahan Baku Langsung & & & \\
Papan Jati & $(2.350 .000)$ & 0 & $(2.350 .000)$ \\
Kaca & $(78.000)$ & 0 & $(78.000)$ \\
Kayu Balok & $(1.000 .000)$ & 0 & $(1.000 .000)$ \\
Busa Grade A & $(600.000)$ & 0 & $(600.000)$ \\
Tenaga Kerja Langsung & & & \\
Bagian Pembuat Pola & $(130.000)$ & 0 & $(130.000)$ \\
Bagian Perakitan & $(195.000)$ & 0 & $(195.000)$ \\
Bagian Jok/Sofa/Busa & $(200.000)$ & 0 & $(130.0000)$ \\
Bagian Finishing & $(130.000)$ & 0 & $(1.294 .000)$ \\
Biaya Overhead Pabrik & & & $(1.321)$ \\
Biaya Bahan Baku Tidak Langsung & $(1.294 .000)$ & 0 & 921.679 \\
Biaya Listrik & $(1.321)$ & 0 & 0 \\
\hline \multicolumn{1}{c}{ Total } & 921.679 & 0 & \\
\hline
\end{tabular}

Sumber: Data yang diolah (2020)

Tabel 7. Biaya Relevan pada Pesanan Khusus 1 Unit Kursi Tamu Ganesha

\begin{tabular}{lrrr}
\hline \multicolumn{1}{c}{ Keterangan } & Menerima (Rp) & Menolak (Rp) & Manfaat Jika Menerima (Rp) \\
\hline Pendapatan & 9.000 .000 & 0 & 9.000 .000 \\
Biaya Bahan Baku Langsung & & & \\
Papan Jati & $(4.935 .000)$ & 0 & $(4.935 .000)$ \\
Kaca & $(78.000)$ & 0 & $(78.000)$ \\
Kayu Balok & $(1.000 .000)$ & 0 & $(1.000 .000)$ \\
Busa Grade A & $(750.000)$ & 0 & $(750.000)$ \\
Biaya Tenaga Kerja Langsung & & & \\
Bagian Pembuat Pola & $(130.000)$ & 0 & $(130.000)$ \\
Bagian Perakitan & $(195.000)$ & 0 & $(195.000)$ \\
Bagian Jok/Sofa/Busa & $(200.000)$ & 0 & $(1300.000)$ \\
Bagian Finishing & $(130.000)$ & 0 & $(1.751 .000)$ \\
Biaya Overhead Pabrik & & & $(1.321)$ \\
Biaya Bahan Baku Tidak Langsung & $(1.751 .000)$ & 0 & $(170.321)$ \\
Biaya Listrik $\quad(1.321)$ & 0 & 0 \\
\hline \multicolumn{1}{c}{ Total } & $(170.321)$ & & \\
\hline
\end{tabular}

Sumber: Data yang diolah (2020) 
Tabel 8. Biaya Relevan pada Pesanan Khusus 1 Unit Meja Ketapang

\begin{tabular}{lrrr}
\hline \multicolumn{1}{c}{ Keterangan } & Menerima (Rp) & Menolak (Rp) & Manfaat Jika Menerima (Rp) \\
\hline $\begin{array}{l}\text { Pendapatan } \\
\text { Bahan Baku Langsung }\end{array}$ & 2.500 .000 & 0 & 2.500 .000 \\
Papan Jati & $(1.000 .000)$ & 0 & \\
Kaca & $(80.000)$ & 0 & $(1.000 .000)$ \\
Tenaga Kerja Langsung & & & \\
Bagian Pembuat Pola & $(150.000)$ & 0 & $(150.0000)$ \\
Bagian Perakitan & $(225.000)$ & 0 & $(225.000)$ \\
Bagian Jok/Sofa/Busa & $(240.000)$ & 0 & $(240.000)$ \\
Bagian Finishing & $(150.000)$ & 0 & $(150.000)$ \\
Biaya Overhead Pabrik & & & \\
Biaya Bahan Baku Tidak Langsung & $(467.500)$ & 0 & $(467.500)$ \\
Biaya Listrik & $(869)$ & 0 & $(869)$ \\
\hline \multicolumn{1}{c}{ Total } & 186.631 & 0 & 186.631 \\
\hline
\end{tabular}

Sumber: Data yang diolah (2020)

Berdasarkan analisis biaya relevan dapat diketahui keputusan perusahaan untuk menerima pesanan khusus 1 unit Kursi Tamu Monalisa, pesanan khusus 1 unit Kursi Tamu Gloria, dan pesanan khusus 1 unit Meja Ketapang memberikan laba bagi perusahaan walaupun harga yang ditawarkan pembeli merupakan harga di bawah penjualan normal dan ukuran yang diminta pembeli diluar dari ukuran normal penjualan perusahaan. Namun, berdasarkan analisis tersebut diketahui telah terjadi kerugian pada pesanan khusus 1 unit Kursi Tamu Ganesha. Kerugian dan juga kecilnya keuntungan perusahaan atas pesanan khusus tersebut terjadi karena perusahaan belum memperhitungkan biaya relevan dan tidak memperkirakan akan adanya beban penyusutan atas aset tetap perusahaan.

Analisis biaya relevan sangat bermanfaat untuk diterapkan dalam perusahaan pada beberapa kesempatan tertentu (Macpal \& Ilat, 2014). Alternatif ini berpengaruh dalam laba perusahaan apabila perusahaan menerima pesanan khusus. Alternatif penerapan perhitungan biaya relevan yang diajukan mampu memberikan keuntungan bagi perusahaan (Pesik, Tinangon, \& Pinatik, 2015). Analisis tersebut menunjukkan pesanan khusus dapat diterima atau ditolak.

\section{Kesimpulan}

Pemisahan dan klasifikasi antara biaya relevan dan biaya tidak relevan pada Dalem Agung Furniture belum dilakukan, sehingga perusahaan belum melakukan perhitungan biaya relevan dalam pengambilan untuk menerima ataupun menolak pesanan khusus dari pembeli.

Perusahaan sebaiknya memperhitungkan biaya relevan terlebih dahulu sebelum mengambil keputusan untuk menerima ataupun menolak pesanan khusus dari pembeli. Hal ini untuk meminimalisir kerugian dan dapat dijadikan strategi perusahaan dalam meningkatkan laba.

\section{Daftar Pustaka}

Istimewa. (2017, Maret 11). 3 Potensi Industri Furniture untuk Indonesia. Dipetik April 18, 2019, dari Liputan6.com: https://www.liputan6.com/bisnis/read/2882681/3potensi-industri-furnitur-untuk-indonesia

Lanen, W. N., Anderson, S. W., \& Maher, M. W. (2017). Dasar-Dasar Akuntansi Biaya Edisi 4 Buku 1. Jakarta: Salemba Empat.

Macpal, O., \& Ilat, V. (2014). Analisis Biaya Relevan untuk Menerima atau Menolak Pesanan Khusus pada UD Sinar Sakti. 2(3), 236-244.

Martini, R., Thoyib, M., Periansya, P. (2018). Upaya Pengembangan Usaha dan Rencana Keuangan: Lakso Sriwijaya. Mitra - Jurnal Pengabdian Masyarakat, 2(1), 52-64.

Martini, R., Zulkifli, Z., Sukmini, H., \& Armaini, R. (2018). Pembukuan dan Pelaporan Informasi Akuntansi Keuangan Berbasis PSAK 45: pada Panti Asuhan Al-Amanah. Aptekmas: Aplikasi Teknologi Bagi Masyarakat, 2(1), 15-22. doi: 10.36257/apts.v1i2.1205.

Pesik, R. R., Tinangon, J. J., \& Pinatik, S. (2015). Analisis Biaya Relevan dalam Pengambilan Keputusan Menerima atau Menolak Pesanan Khusus pada PT Perikanan Nusantara Cabang Bitung. 3(1), 129-136

Pers. (2019, Maret 14). Masih Ekspansif, Industri Manufaktur Dongkrak Ekonomi Tumbuh Signifikan. Retrieved April 18, 2019, from kemenperin.go.id: http://www.kemenperin.go.id/artikel/20429/MasihEkspansif,-Industri-Manufaktur-DongkrakEkonomi-Tumbuh-Signfikan

Rohana, I. S., \& Sunrowyati, S. (2016). Analisis Biaya Relevan untuk Pesanan Khusus Guna Meningkatkan Laba Perusahaan Kasur "UD. Afina Rizki". Riset Mahasiswa Ekonomi (RITMIK), 3(3),229-247. 
Salman, K. R., \& Farid, M. (2016). Akuntansi Manajemen: Alat Pengukur dan Pengambilan Keputusan Manajerial. Jakarta: Indeks.

Siregar, B., Suripto, B., Hapsoro, D., Lo, E. W., \& Biyanto, F. (2017). Akuntansi Manajemen. Jakarta: Salemba Empat.

Tumilantouw, F., Morasa, J., \& Kalangi, L. (2014). Penerapan Biaya Relevan dalam Pengambilan Keputusan Menerima atau Menolak Pesanan Khusus pada CV. Pyramid. Jurnal EMBA, 2(1), 677-685.
Wibowo, A., \& Purwanugraha, A. (2012). Analisis Biaya Relevan untuk Pengambilan Keputusan Mempertahankan atau Menghentikan Segmen Perusahaan pada CV. Podo Kumpul. Jurnal EMBA, 2(4), 223-232.

Z., M., Martini, R., \& Agustin, M. (2019). Harga Pokok Produksi untuk Penentuan Harga Jual Kain Tenun Songket Melati Desa Burai Kabupaten Ogan Ilir. Aptekmas: Aplikasi Teknologi Bagi Masyarakat, 2(3), 31-38. doi: 10.36257/apts.v2.i3.1842. 